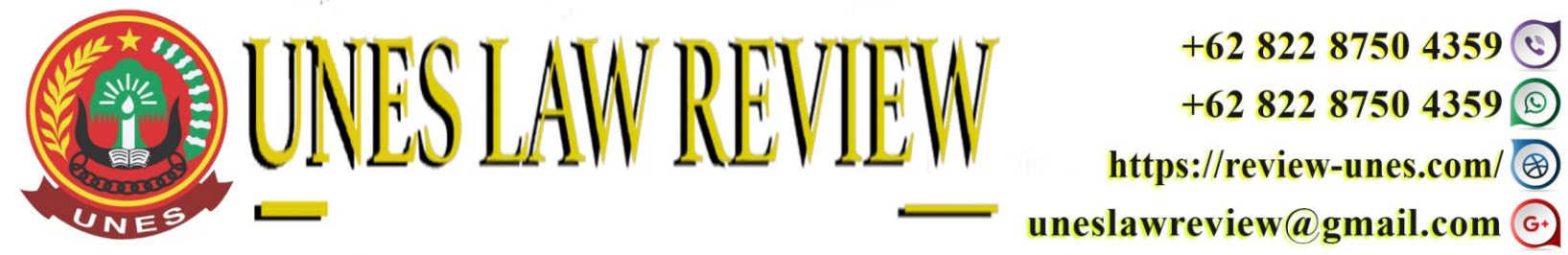

DOI: https://doi.org/10.31933/unesrev.v3i1

Diterima: 28/08/2020, Diperbaiki: 20/09/2020, Diterbitkan: 23/09/2020

\title{
PENYELESAIAN TUNGGAKAN REKENING AIR PERUSAHAAN DAERAH AIR MINUM (PDAM) KOTA PADANG OLEH JAKSA SELAKU PENGACARA NEGARA (Studi pada Kejaksaan Negeri Padang)
}

\author{
Depi Hartato \\ Kejaksaan Tinggi Sumatera Barat, Padang, Indonesia. \\ Email: depi_htt20@gmail.com
}

Corresponding Author: Depi

\section{ABSTRACT}

This research examines the implementation of the Settlement of Water Account Arrears at the Padang City Water Company (PDAM) by the Prosecutor as State Lawyer (Study at the Padang State Prosecutor's Office). This research is a descriptive analytical study. The approach method used in this research is juridical normative with an empirical approach, using secondary and primary data collected through literature and field studies with data collection techniques through interviews and documentation. The results showed that: PDAM has billed but not getting the maximum results, Kejari Padang is experienced in helping to settle arrears for customers of PT Permodalan Nasional Madani (Persero) Tbk and PDAM continues to cooperate with Kejari Padang. Second, the settlement of water account arrears for PDAM Kota Padang customers by the Prosecutor as the State Attorney is that the PDAM contacts the Padang Prosecutor's Office and coordinates regarding the material of the problem so that JPN digs up the problem, if it enters the civil realm then the PDAM makes a Special Power of Attorney as the basis for JPN to call customers who are in default, Some customers who have been summoned have paid in full and some have paid in installments (made a full payment statement), if the agreement cannot be reached, JPN will make a report to the leadership and the leadership to report to the PDAM that the resolution of the problem can be done through a litigation process.

Kata Kunci: Penyelesaian Tunggakan, Jaksa, Pengacara Negara

\section{PENDAHULUAN}

Pasal 30 Ayat (2) Undang-Undang Nomor 16 Tahun 2004 tentang Kejaksaan Republik Indonesia mengatur tentang tugas dan wewenang Kejaksaan dalam bidang perdata yang berbunyi: 
"Di bidang perdata dan tata usaha negara, Kejaksaan dengan kuasa khusus dapat bertindak baik di dalam maupun di luar pengadilan untuk dan atas nama negara atau pemerintah."

Tugas dan wewenang Kejaksaan di bidang perdata bukanlah hal yang baru karena dasar hukum dan pelaksanaanya telah ada sejak perundang-undangan Hindia Belanda. Pasal 2 Koninklijk Besluit (Keputusan Ratu Belanda) antara lain memuat ketentuan bahwa dalam sengketa yang diadili menurut acara sipil (perdata) bertindak untuk pemerintah Indonesia sebagai wakil negara dalam tingkat pertama opsir yustisi atau Jaksa atau pegawai yang menjalankan tugas Jaksa (Jam Datun, 1997:207).

Hal ini merupakan upaya dari kekuasaaan legislatif didalam rangka memantapkan kedudukan dan peranan Kejaksaan agar lebih mampu dan berwibawa dalam melaksanakan tugas dan wewenangnya dalam negara hukum yang berdasarkan pancasila. Didalam negara hukum yang menyelenggarakan kesejahteraan masyarakat akan banyak ditemukan keterlibatan dan kepentingan hukum dari negara dan pemerintah di bidang perdata, baik dalam kedudukan sebagai tergugat maupun sebagai penggugat atau pihak yang mempunyai kepentingan hukum diluar pengadilan yang dapat diwakilkan kepada Kejaksaan.

Pasal 3 Peraturan Jaksa Agung Nomor 040/A/J.A/12/2010 tentang Standar Operasional Prosedur (SOP) Pelaksanaan Tugas dan Fungsi Wewenang Perdata dan Tata Usaha Negara, yakni:

1. Bantuan Hukum, adalah tugas Jaksa Pengacara Negara dalam perkara perdata dan tata usaha negara untuk mewakili lembaga negara, instansi pemerintah pusat/daerah, BUMN/BUMD berdasarkan surat kuasa khusus sebagai penggugat maupun tergugat yang dilakukan secara litigasi maupun non litigasi.

2. Pertimbangan Hukum, adalah tugas Jaksa Pengacara Negara untuk memberikan pendapat hukum (Legal Opinion) dan atau pendampingan (Legal Assistance) di bidang perdata dan tata usaha negara atas dasar permintaan dari lembaga negara, instansi pusat dan daerah, BUMN/BUMD

3. Pelayanan Hukum, adalah tugas Jaksa Pengacara Negara untuk memberikan penjelasan tentang masalah hukum perdata dan tata usaha negara kepada anggota masyarakat yang meminta.

4. Penegakan Hukum, adalah tugas Jaksa Pengacara Negara untuk mengajukan gugatan atau permohonan kepada pengadilan di bidang perdata sebagaimana ditetapkan oleh peraturan perundang-undangan dalam rangka memelihara ketertiban umum, kepastian hukum, dan melindungi kepentingan negara dan pemerintah serta hak keperdataan masyarakat, antara lain: pembatalan perkawinan, pembubaran perseroan terbatas dan pernyataan pailit.

5. Tindakan Hukum Lain adalah, tugas Jaksa Pengacara Negara untuk bertindak sebagai mediator atau fasilitator dalam hal terjadi sengketa atau perselisihan antar lembaga negara, instansi pusat dan daerah, BUMN/BUMD di bidang perdata dan tata usaha negara.

Salah satu tugas Kejaksaan di bidang Perdata dan Tata Usaha Negara bertugas yakni mewakili pemerintah dalam beracara perdata yang biasanya dikenal dengan sebutan Jaksa Pengacara Negara. Lahirnya Jaksa Pengacara Negara dalam tubuh Kejaksaan dibentuk pada tahun 1991, yaitu pada masa kepemimpinan Suhadibroto. Kala itu konsep awal dibentuknya Jaksa Pengacara Negara ialah meniru dari Konsep Australia yang memiliki Solicitor-General 
sebagai Jaksa Pengacara Negara. Namun perbedaannya ialah bahwa pengadoposian tersebut dilakukan dengan memasukan Jaksa Pengacara Negara berada didalam Kejagung, yang mana dinegara asalnya Jaksa Pengacara Negara merupakan sebuah kantor sendiri yang berisi profesional hukum.

Jaksa Pengacara Negara adalah Jaksa dengan Kuasa Khusus, bertindak untuk dan atas nama Negara atau Pemerintah dalam melaksanakan tugas dan wewenang Kejaksaan dibidang perkara Perdata dan Tata Usaha Negara, Sebagai Kuasa dari Instansi Pemerintah atau BUMN/BUMD, Jaksa Pengacara Negara diwakili oleh Kejaksaan sebagai Jaksa Pengacara Negara berdasarkan Surat Kuasa Khusus (SKK), Tidak semua jaksa otomatis menjadi Jaksa Pengacara Negara karena penyebutan itu hanya kepada jaksa-jaksa yang secara struktural dan fungsional melaksanakan tugas-tugas Perdata dan Tata Usaha Negara (Datun).

PDAM Kota Padang sebagai sebagai perusahaan milik Pemda Kota Padang, memberikan manfaat air bersih bagi masyarakat dan membebani masyarakat tersebut dengan sebuah kewajiban secara pasti. Namun seringkali timbul permasalahan diantaranya kelalaian pelanggan untuk melakukan pembayaran rekening air yang mengakibatkan tunggakan atau piutang bagi PDAM Kota Padang. Tunggakan ini berasal dari masyarakat umum dan instansi pemerintah (rumah dinas dan asrama) dengan nilai tunggakan ratusan juta rupiah. Pihak PDAM Kota Padang sudah melakukan penagihan langsung ke lapangan namun tidak mendapatkan hasil yang maksimal, dikarenakan pelanggan yang menunggak tersebut tidak berada ditempat dan ada yang menyanggah tagihan tersebut.

Seiring dengan terjadinya wanprestasi, bentuk penyelesaian diluar pengadilan dipakai oleh PDAM Kota Padang untuk mengatasi masalah tunggakan rekening air dari pelanggan. PDAM Kota Padang telah melakukan kesepakatan dengan Kejaksaan Negeri Padang, dimana Kejaksaan diminta untuk memberikan Bantuan Hukum, Pertimbangan Hukum, dan Tindakan Hukum Lain di bidang Perdata dan Tata Usaha Negara kepada PDAM Kota Padang yang selanjutnya PDAM Kota Padang menyerahkan Surat Kuasa Khusus (SKK) kepada Kepala Kejaksaan Negeri Padang guna bertindak untuk dan atas nama PDAM Kota Padang baik didalam pengadilan maupun diluar pengadilan.

Untuk mengetahui secara lebih jelas, dalam tulisan ini dibahas mengenai Jaksa Pengacara Negara, khususnya dalam penyelesaian tunggakan rekening air dari pelanggan PDAM Kota Padang. Berdasarkan isu-isu hukum di atas, maka perlu dilakukan penelitian tentang :

1. Apa latar belakang PDAM Kota Padang meminta bantuan Jaksa selaku Pengacara Negara dalam Penyelesaian tunggakan rekening air pelanggan?

2. Bagaimana penyelesaian tunggakan rekening air pelanggan PDAM Kota Padang oleh Jaksa selaku Pengacara Negara?

\section{METODE PENELITIAN}

Spesifikasi penelitian ini adalah deskriptif analitis. Metode pendekatan yang digunakan dalam penelitian ini adalah yuridis normatif sebagai pendekatan utama dan didukung dengan pendekatan yuridis empiris. Pendekatan yuridis empiris adalah pendekatan yang menekankan pada aspek hukum dilapangan dikaitkan dengan aturan yang berlaku. Hal ini berarti melakukan 
pendekatan yang menekankan pada praktek dilapangan dikaitkan dengan aspek hukum atau perundang-undangan yang berlaku (Hadari Nawawi dalam Soejono, 2003:23).

Data yang digunakan dalam penelitian ini mencakup sekunder sebagai data utama, dan data primer sebagai pendukung. Teknik pengumpulan data dilakukan dengan 2 (dua) cara yaitu pengumpulan data primer dilakukan dengan cara penelitian lapangan dan pengumpulan data sekunder dilakukan dengan cara penelitian kepustakaan. Data yang diperoleh dari penelitian dianalisis secara yuridis kualitatif dengan cara memberikan komentar dan disajikan secara deskriptif analisis yaitu hanya akan menggambarkan saja dari hasil penelitian yang berhubungan dengan pokok permasalahan.

\section{HASIL DAN PEMBAHASAN}

\section{Latar belakang PDAM Kota Padang meminta bantuan Jaksa selaku Pengacara Negara dalam Penyelesaian tunggakan rekening air pelanggan.}

Setelah dilakukan penelitian bahwa yang melatarbelakangi pihak PDAM Kota Padang meminta bantuan kepada Kejaksaan Negeri Padang dalam hal ini Jaksa Pengacara Negara untuk menyelesaikan tunggakan rekening air pelanggan yang wanprestasi antara lain disebabkan oleh usaha maksimal yang dilakukan PDAM Kota Padang tidak membuahkan hasil yang memuaskan, terutama pada komplek asrama atau rumah dinas dan sejumlah rumah warga. Malah ada yang menantang petugas PDAM Kota Padang karena merasa tidak mendapatkan pelayanan yang maksimal.

Latarbelakang lain Pihak PDAM Kota Padang meminta bantuan Kejaksaan Negeri Padang yaitu Kejaksaan Negeri Padang melalui Jaksa Pengacara Negara telah berpengalaman dalam membantu Badan Usaha Milik Negara dalam menyelesaikan kredit macet dari krediturnya. PT Permodalan Nasional Madani (Persero) Tbk atau biasa disebut PT PNM merupakan salah satu BUMN yang telah dibantu oleh Kejaksaan Negeri Padang dalam menangani permasalahan kredit macet dan mendapatkan hasil yang sangat baik.

PDAM Kota Padang juga melanjutkan program kerjasama antara dengan Kejaksaan Negeri Padang yang sempat terhenti pada tahun 2014 dikarenakan salah satu Direksi PDAM Kota Padang waktu itu tersangkut masalah hukum yang sedang ditangani Kejaksaan.

Kerjasama itu dilanjutkan lagi karena pihak PDAM Kota Padang menilai bahwa penyelesaian tunggakan rekening air pelanggan oleh Jaksa Pengacara Negara Kejaksaan Negeri Padang berjalan efektif. Kebanyakan pelanggan yang menunggak pembayaran rekening air yang mendapatkan Surat Panggilan dari Kejaksaan Negeri Padang membayar tunggakannya.

Menurut Pasal 30 Ayat (2) Undang-Undang Nomor 16 Tahun 2004 Tentang Kejaksaan Republik Indonesia menyatakan adanya kewenangan di bidang perdata dan tata usaha negara dengan kuasa khusus dapat bertindak baik didalam maupun diluar pengadilan untuk atas nama negara/pemerintah, dalam pelaksanaannya dilakukan oleh Jaksa Pengacara Negara. Pelanggan PDAM Kota Padang yang menunggak pembayaran telah melakukan wanprestasi, dimana mereka dianggap lalai dan ingkar janji dalam melaksanakan kewajibannya. Para Pelanggan terlambat dalam memenuhi prestasinya. Dalam keadaan inilah PDAM Kota Padang sebagai BUMD 
melakukan tindakan tegas dalam urusan keperdataan untuk menyelesaikan wanprestasi ini. Salah satunya dengan meminta bantuan Jaksa Pengacara Negara untuk proses litigasi maupun non litigasi.

Pemerintah mempunyai fungsi pokok antara lain dalam sektor bisnis yakni kegiatan yang teratur dan berkelanjutan dalam melayani kebutuhan umum atau kebutuhan masyarakat sambil menciptakan dan memperoleh pendapatan, adapun bisnis pemerintah adalah mengejar laba yang diwujudkan lewat Badan Usaha Milik Negara (BUMN) dan Badan Usaha Milik Daerah (BUMD) sebagai wujud nyata investasi negara dalam dunia usaha dengan tujuan untuk memacu dan mendorong perekonomian negara, sedangkan tujuan pendirian BUMD adalah sebagaimana dinyatakan dalam Pasal 7 Peraturan Pemerintah Nomor 54 Tahun 2017 tentang Badan Usaha Milik Daerah menyatakan bahwa:

1. Memberikan manfaat bagi perkembangan perekonomian daerah.

2. Menyelenggarakan kemanfaatan umum berupa penyediaan barang dan/atau jasa yang bermutu bagi pemenuhan hajat hidup masyarakat sesuai kondisi, karakteristik dan potensi daerah yang bersangkutan berdasarkan tata kelola perusahaan yang baik.

3. Memperoleh laba dan/atau keuntungan.

Sebagai badan hukum melakukan berbagai tindakan melalui manusia atau pengurus yang bertindak selaku wakil dari badan hukum yang bersangkutan. Jadi dapat dikatakan bahwa BUMD adalah salah satu organ pemerintah baik pusat maupun daerah. Hal ini dapat dilihat dalam undang-undang tentang BUMD yakni : Pasal 1 angka 1 Peraturan Pemerintah Nomor 54 Tahun 2017 yang menyatakan bahwa :

"Badan Usaha Milik Daerah yang selanjutnya disebut BUMD, adalah badan usaha yang seluruh atau sebagian besar modalnya dimiliki oleh daerah.

Pasal 1 Angka 9 Peraturan Pemerintah Nomor 54 Tahun 2017 yang menyatakan bahwa :

"Tata kelola perusahaan yang baik adalah sistem pengelolaan yang mengarahkan dan mengendalikan perusahaan agar menghasilkan kemanfaatan ekonomi yang berkesinambungan dan keseimbangan hubungan antar pemangku kepentingan.”

Pasal 4 ayat (1) menyatakan "Kepala Daerah mewakili Pemerintah Daerah dalam kepemilikan kekayaan daerah yang dipisahkan pada : a) perusahaan umum daerah, berkedudukan sebagai pemilik modal; b) Perusahaan Perseroan Daerah, berkedudukan sebagai pemegang saham. Ayat (2) menyatakan "Kepala daerah selaku pemilik modal pada perusahaan umum daerah atau pemegang saham pada perusahaan perseroan daerah mempunyai kewenangan mengambil keputusan".

Dalam melakukan tindakan non litigasi Jaksa Pengacara Negara bertindak menjadi mediator atau fasilitator dan tidak mewakili salah satu pihak, namun Jaksa Pengacara Negara disini bertindak pasif selaku penengah/mediator dengan memfasilitasi solusi bagi penyelesaian sengketa keperdataan dalam proses mmeediasi. Dalam menjalankan tugas di bidang perdata, kejaksaan terus berupaya meningkatkan kepercayaan dan kepuasan pemberi kuasa dalam hal ini negara, dengan kinerja yang berhasil guna dan berdaya guna serta proaktif untuk menjual jasa di bidang perdata sebagai "Kantor Pengacara Negara" dengan cara membina hubungan dengan 
instansi lain dan melakukan persentase mengenai apa dan bagaimana serta keuntungan dan kelebihan Jaksa Pengacara Negara.

\section{Penyelesaian tunggakan rekening air pelanggan PDAM Kota Padang oleh Jaksa selaku Pengacara Negara.}

Dalam mendapatkan haknya, PDAM Kota Padang menggunakan cara non litigasi dibandingkan litigasi dalam penyelesaian tunggakan rekening air dari pelanggan yang wanprestasi tersebut dengan melibatkan pihak ketiga yang netral diluar para pihak dalam bentuk mediasi, dalam hal penyelesaian tunggakan rekening air pelanggan PDAM Kota Padang ini melibatkan Kejaksaan Negeri Padang selaku mediator. Jauh sebelumnya PDAM Kota Padang telah terlebih dahulu melakukan penyelesaian tunggakan rekening air ini dengan cara kekeluargaan dengan memberikan surat teguran kepada pelanggan sebanyak dua kali, apabila surat tersebut masih belum dihiraukan oleh pelanggan kemudian baru PDAM Kota Padang meminta bantuan Jaksa Pengacara Negara melakukan pemanggilan untuk mediasi.

Kerjasama PDAM Kota Padang dengan Kejaksaan Negeri Padang dalam menangani penyelesaian tunggakan rekening air dituangkan dalam Surat Kuasa Khusus, diantaranya menyatakan dengan suatu perjanjian yang lebih lanjut, pihak kedua bersedia memberikan bantuan hukum, pelayanan hukum, pertimbangan hukum, dan tindakan hukum lainnya untuk kepentingan pihak pertama serta bersedia melakukan negoisasi dan atau bertindak sebagai mediator dalam proses penyelesaian perkara secara mediasi untuk kepentingan pihak pertama sesuai dengan kuasa khusus yang diberikan dalam hal terjadi sengketa perdata khususnya Pelanggan PDAM Kota Padang yang wanprestasi ini.

Dengan diberikannya hak khusus untuk membuat dan menandatangani jawaban gugatan serta surat-surat lainnya yang berhubungan; memberi atau menyanggah; keterangan-keterangan atau bukti; menghadirkan atau menolak kehadiran saksi-saksi; menyanggah keterangan saksi; melakukan/melayani upaya hukum termasuk banding dan kasasi; serta membuat dan menandatangani memori atau kontra memori; menghubungi instansi pengadilan tingkat pertama, banding, kasasi serta instansi lainnya yang berhubungan; dan melakukan tindakan hukum lain baik di luar maupun di dalam pengadilan yang dianggap perlu dan bermanfaat bagi penyelesaian perkara (Frans Hendra Winata, 2011:23).

PDAM Kota Padang mengeluarkan Surat Kuasa Khusus kepada Kejaksaan Negeri Padang guna bertindak untuk dan atas nama PDAM Kota padang dalam masalah hukum perdata. Hasil penelitian menggambarkan beberapa poin dalam Surat Kuasa Khusus itu isinya :

1. Melakukan penagihan, menerima hasil penagihan, menandatangani surat-surat / dokumen yang berkenaan dengan tindakan penagihan dan menerima hasil penagihan untuk disetorkan kepada pemberi kuasa.

2. Melakukan tindakan hukum lainnya yang berkenaan dengan usaha penagihan dan penyelesaian kredit macet yang telah diserahkan, didalam dan diluar pengadilan sepanjang tak bertentangan dengan perundang-undangan.

3. Melakukan pemeriksaan terhadap lokasi usaha dan barang agunan kredit debitur. 
4. Membuat dan menandatangani Surat Panggilan kepada pelanggan untuk datang pada kantor penerima kuasa.

5. Menghadap pejabat instansi manapun yang berkaitan dengan usaha penagihan dan penyelesaian tunggakan rekening air yang bermasalah.

6. Membuat progress report terhadap pemberi kuasa secara berkala.

Penyelesaian tunggakan rekening air pelanggan PDAM Kota padang oleh Jaksa Pengacara Negara dilaksanakan berdasarkan Surat Kuasa Khusus, sesuai dengan format yang telah ditentukan. Selanjutnya Jaksa Pengacara Negara melakukan koordinasi dengan Pemberi Kuasa terkait dengan materi perkara, untuk mendapatkan masukan dan informasi secara maksimal dalam penanganan perkara serta Jaksa Pengacara Negara harus menguasai materi yang mencakup kasus posisi, alat bukti yang diperlukan dan hal-hal lain yang relevan.

Jaksa Pengacara Negara melakukan komunikasi dengan pihak lawan berperkara baik secara non formal maupun secara formal dengan mengundang pihak lawan untuk melakukan negosiasi, bila perlu mengikutsertakan pihak Pemberi Kuasa. Penyelesaian tunggakan rekening air dari Pelanggan PDAM Kota Padang yang dilakukan dengan proses mediasi oleh tim jaksa selaku mediator dilakukan dengan cara pendekatan persuasif. Caranya adalah wawancara formal dengan terlebih dahulu melakukan prosedur pemanggilan resmi bagi pelanggan PDAM Kota Padang yang menunggak untuk datang ke kantor Kejaksaan Negeri Padang. Isi dari surat panggilan adalah meminta kedatangan para Pelanggan PDAM Kota Padang untuk diminta keterangan langsung sehubungan dengan kasus tunggakan rekening air tersebut.

Hasil penelitian menunjukkan bahwa pelanggan datang untuk memenuhi panggilan sesuai dengan waktu dan tempat yang telah ditentukan. Materi wawancara telah disiapkan oleh mediator meliputi identitas pelanggan yang menunggak, kebenaran pelanggan yang menunggak masih berstatus pelanggan PDAM Kota Padang, apakah ada niat baik dari debitur, apakah bisa dilakukan pelunasan, dan lain-lain.

Setiap tindakan Jaksa Pengacara Negara dalam melakukan negosiasi harus dikoordinasikan dengan Pemberi Kuasa dan setiap tahap negosiasi dilaporkan kepada Pimpinan dan Pemberi Kuasa sesuai dengan Administrasi Perkara Perdata dan Tata Usaha Negara.

Dalam pelaksanaan negosiasi Jaksa Pengacara Negara harus berpegang pada Pasal 1320 KUHPerdata dan wajib memahami ruang lingkup Keuangan Negara dan Kekayaan Negara berdasarkan peraturan perundang- undangan yang berlaku baik sebagai Kekayaan Negara yang dipisahkan maupun sebagai Kekayaan Negara yang tidak dipisahkan guna mengantisipasi adanya suatu Kerugian Keuangan Negara yang telah ada maupun yang berpotensi diakibatkan oleh suatu permasalahan yang diajukan oleh Pemohon guna menghindari adanya legitimasi melalui mekanisme keperdataan atas suatu perbuatan tindak pidana korupsi.

Hasil analisis deskripsi menggambarkan bahwa pelanggan yang menunggak, khususnya pelanggan yang menunggak dalam jumlah kecil berusaha secepatnya melakukan pelunasan langsung tunggakan rekening air dengan cara datang langsung ke PDAM Kota Padang untuk menyelesaikan hutangnya selama ini. Pelanggan dengan tunggakan dalam jumlah kecil kebanyakan melakukan pelunasan setelah pulang dari Kejaksaan Negeri Padang, bahkan ada 
yang datang ke kantor jaksa untuk menunjukan bahwa dirinya telah menyelesaikan kewajibannya di PDAM Kota Padang. Pelanggan lain yang tunggakan rekening airnya lebih besar biasanya membuat kesepakatan dihadapan Jaksa Pengacara Negara yang ada di Kejaksaan Negeri Padang bahwa ia bersedia melakukan pelunasan tunggakan secara angsuran, biasanya diberikan jangka waktu 3 (tiga) kali angsuran.

Cara pelunasan sepenuhnya ditentukan sendiri di hadapan Jaksa Pengacara Negara sebagai mediator. Dengan petunjuk atau arahan jaksa, pelanggan membuat surat pernyataan dengan bermaterai cukup, dengan pokok inti pernyataan tentang kesanggupan cara pembayaran dan jangka waktu pelunasan. Surat pernyataan tersebut dibuat rangkap 3 (tiga), dengan surat pernyataan asli dipegang oleh Jaksa selaku mediator dan masing-masing satu lembar tembusan untuk bersangkutan dan pihak PDAM Kota Padang.

Peran anggota tim Jaksa Pengacara Negara sebagai mediator dalam menyelesaikan tunggakan rekening air dari pelanggan PDAM Kota Padang adalah memberikan arahan dan mengingatkan kewajiban yang harus dijalankan setelah pelanggan menikmati manfaat air dari PDAM Kota Padang sesuai dengan ketentuan yang tercantum dalam surat persetujuan antara pelanggan dengan PDAM Kota Padang yang telah ditandatangani oleh kedua belah pihak. Mediator juga memberikan arahan untuk sedapat mungkin menyelesaikan tunggakan rekening air ini di luar pengadilan, sebab cara penyelesaian dengan mediasi antara pelanggan dan PDAM Kota Padang melalui pihak ketiga tidak bertentangan dengan aturan hukum yang berlaku di Indonesia. Penyelesaian sengketa di luar pengadilan diupayakan untuk menyelesaikan perkara secara cepat, hemat dan tepat.

Bila dalam negosiasi dicapai kesepakatan perdamaian, maka kesepakatan tersebut dituangkan dalam Kesepakatan Perdamaian yang ditandatangani para pihak dan saksi, disesuaikan dengan bobot perkara. Penanganan perkara Non Litigasi dinyatakan selesai dengan adanya kesepakatan para pihak maupun sepakat untuk tidak menempuh perdamaian. Terhadap kesepakatan para pihak yang dituangkan dalam Kesepakatan Perdamaian, apabila pihak lain ingkar janji (wanprestasi), Pemberi Kuasa dapat memberikan kuasa khusus baru kepada Jaksa Pengacara Negara untuk merealisasikan Kesepakatan Perdamaian tersebut.

Apabila dalam negosiasi tersebut tidak dapat dicapai Kesepakatan Perdamaian, maka Jaksa Pengacara Negara wajib membuat laporan kepada Pimpinan selanjutnya Pimpinan meneruskan kepada Pemberi Kuasa dengan saran bahwa penyelesaian perkara tersebut dapat dilakukan melalui Litigasi. Batas waktu penyelesaian perkara secara Non Litigasi mengikuti ketentuan peraturan Standard Operasional Prosedur Penanganan Perkara Perdata dan Tata Usaha Negara yang berlaku.

\section{KESIMPULAN}

Berdasarkan hasil penelitian dan analisis yang telah diuraikan dalam bab-bab sebelumnya, maka disimpulkan hal-hal sebagai berikut:

1. Latarbelakang PDAM Kota Padang meminta bantuan Jaksa selaku Pengacara Negara dalam Penyelesaian tunggakan rekening air pelanggan yaitu : Pihak PDAM Kota Padang 
telah menagih dengan maksimal namun tidak mendapatkan hasil yang memuaskan bahkan mendapat perlawanan dan Kejari Padang telah berpengalaman membantu PT Permodalan Nasional Madani (Persero) Tbk dalam menyelesaikan tunggakan kredit nasabahnya serta PDAM Kota Padang melanjutkan kembali kerjasama dengan Kejari Padang.

2. Penyelesaian tunggakan rekening air Pelanggan PDAM Kota Padang oleh Jaksa selaku Pengacara Negara adalah sebagai berikut: a) PDAM menghubungi dan berkoordinasi dengan Kejari Padang terkait permasalahan; b) Kejari Padang dalam hal ini Jaksa Pengacara Negara menggali dan menilai apakah permasalahan tersebut berada dalam perkara perdata atau pidana; c) Jika pidana, PDAM menerbitkan Surat Kuasa Khusus untuk Kejari Padang sebagai dasar memanggil pelanggan wanprestasi; d) Pelanggan membayar lunas da nada yang menyicil (membuat surat pernyataan akan melunasi; e) Pelanggan yang tidak bayar, maka JPN akan membuat laporan kepada pimpinan selanjutnya pimpinan meneruskan kepada PDAM dengan saran bahwa penyelesaian perkara tersebut dapat dilakukan melalui proses litigasi.

\section{DAFTAR PUSTAKA}

Frans Hendra Winata, Hukum Penyelesaian Sengketa Arbitrase Nasional Indonesia dan Internasional, Sinar Grafika, Jakarta, 2011.

Hadari Nawawi dalam Soejono, Metode Penelitian Hukum, Rineka Cipta, Jakarta, 2003.

Kitab Undang-undang Hukum Perdata

Undang-Undang Nomor 16 Tahun 2004 tentang Kejaksaan Republik Indonesia.

Peraturan Pemerintah Nomor 54 Tahun 2017 tentang Badan Usaha Milik Daerah.

Peraturan Jaksa Agung Nomor 040/A/J.A/12/2010 tentang Standar Operasional Prosedur (SOP) Pelaksanaan Tugas dan Fungsi Wewenang Perdata dan Tata Usaha Negara.

JAM DATUN, Himpunan Informasi dan Petunjuk JAM DATUN Tahun 1997 Buku X, JAM DATUN, Jakarta, 1997.

Kejaksaan Agung Republik Indonesia, Laporan hasil Rapat Kerja Kejaksaan R.I dengan tema "Optimalisasi kinerja dengan mengedepankan peran pegawasan melekat untuk mewujudkan aparatur kejaksaan yang profesional, proporsional dan berhati nurani, Cianjur 20-23 November 2012. 